\title{
SIMULATION MODEL FOR PARTICLE DYNAMICS IN RUMEN OF CATTLE FED SUGARCANE DIET
}

\author{
Edgar Alain Collao-Saenz ${ }^{1 *}$; Jan Dijkstra²; Paulo César de Aguiar Paiva3; André Bannink; \\ Pedro Braga Arcuri ${ }^{5}$; Júlio César Teixeira ${ }^{3}$; Juan Ramón Olalquiaga Pérez $z^{3}$; Flávia Maria David ${ }^{1}$ \\ ${ }^{1}$ UFLA - Programa de Pós-Graduação em Zootecnia, C.P. 37 - 37200-000 - Lavras, MG - Brasil. \\ ${ }^{2}$ WAU - ANU Group - PO Box 338 - 6700AH- Wageningen - The Netherlands. \\ ${ }^{3}$ UFLA - Depto. de Zootecnia, C.P. 37 - 37200-000 - Lavras, MG - Brasil. \\ ${ }_{5}^{4}$ ID-TNO/WAU - ANU Group - PO Box 65 - 8200AB - Lelystad - The Netherlands \\ ${ }^{5}$ Embrapa Gado de Leite R.Eugênio Nascimento, 610 - 36038-330 - Juiz de Fora, MG - Brasil. \\ *Corresponding author <edgarcollao@hotmail.com>
}

\begin{abstract}
Animal simulation models are sets of equations used to describe biological processes. A nonsteady state simulation model of cattle digestion is presented in order to represent nutrient availability as a response to feed intake pattern and the kinetics of particle size reduction. Variables representing the particle size reduction and discontinuous voluntary feed intake were included in a mechanistic model created to optimize the supplementation of sugarcane based diets. In general the predicted values were very close to observed values for fibre and nitrogen flows. The model has not shown consistent bias in relation to the behavior of the observed data of duodenal flow of neutral detergent fiber and non-ammonia nitrogen. Milk production simulations were quite close to actual values. Predictions were improved by the non steady-state model, taking into account variable intake rate in relation to the previous steady-state model. The model can be used to select strategies for supplementation of cattle fed sugarcane based diets.

Key words: dairy cows, milk production, modeling, rumen

\section{MODELO PARA SIMULAÇÃO DA DINÂMICA DE PARTÍCULAS DO ALIMENTO NO RÚMEN DE BOVINOS ALIMENTADOS COM CANA-DE-AÇÚCAR}

\begin{abstract}
RESUMO: Modelos de simulação animal são conjuntos de equações utilizados para descrever processos biológicos. Um modelo de simulação da digestão de bovinos em condições de ingestão descontínua é apresentado com objetivo de representar a disponibilidade de nutrientes como resposta ao padrão de consumo de alimentos e à cinética da redução do tamanho de partícula. Variáveis representando a redução do tamanho de partículas e consumo de alimento descontinuo foram incluídas em um modelo mecanicista criado para aperfeiçoar a suplementação de dietas à base de cana-de-açúcar. Os valores estimados estiveram muito próximos dos valores observados para fluxos de fibra e nitrogênio. O modelo não apresentou desvios consistentes dos valores observados de fluxo duodenal de fibra em detergente neutro e nitrogênio não-amoniacal. A média geral das produções de leite foi estimada com precisão. As estimativas sob condições de disponibilidade variável de nutrientes apresentaram maior precisão quando comparadas com o modelo anterior que assumia consumo continuo de nutrientes. O modelo pode ser usado para selecionar estratégias de suplementação de dietas à base de cana-de-açúcar em vacas em lactação.

Palavras-chave: modelagem, produção de leite, rúmen, vacas leiteiras
\end{abstract}

\section{INTRODUCTION}

In tropical regions, ruminant production systems are based mainly on forages. Among the tropical forages, sugarcane has a high yield of dry matter (DM) and energy (TDN) per unit area, and the forage productivity can reach more than 30 tons of DM per hectare. Sugarcane is usually harvested during the dry season when other fresh forages are not available. Sugarcane has a high potential in ruminant production because, around $30 \mathrm{~kg}$ of daily milk production seems to be attainable with diets containing sugarcane as the only forage (Correa et al., 2003).
Sugarcane has a high content of soluble carbohydrates, whereas the digestibility of the fiber fraction is low. Leng \& Preston (1976) stated that fiber digestibility would not exceed 25\%. Laredo \& Minson (1973) and Allen (2000) indicated a reduction of the voluntary intake due to low diet digestibility and low passage rate, and it is therefore assumed that low rates of ruminal digestion and passage may lead to physical limitations on daily dry matter intake (DMI) that may be achieved. Such a depression in DMI has been observed by Correa et al. (2003) in dairy cows fed sugarcane based diets in comparison to maize 
silage based diets with the same neutral detergent fibre (NDF) content.

Although no significant effects of chopping and grinding of sugarcane on voluntary DMI were reported by Leng \& Preston (1976), other studies suggested a positive effect of a reduction of particle size in poor quality forages with a high cell wall content (Kusmartono et al., 1996). Thus, at least in some circumstances, it seems that reduction of the particle size of feeds may contribute to the effects of rumination and thereby to increase DMI.

Inclusion of new features attempting to increase the accuracy of the simulations usually carries new problems of parameterization and befuddles the performance. The objective of the present study is to extend the model of Dijkstra et al. (1996a) to non-steady state feeding conditions and to enable the model to simulate nutrient availability as a response to feed intake patterns and the kinetics of particle size reduction. The extended model may help in particular to explain the effects of variation in physical and chemical characteristics of tropical feeds on observed milk yields.

\section{MATERIAL AND METHODS}

The inclusion of the new features in the model developed by Dijkstra et al. (1996a) was accomplished at the Animal Science Department of the Wageningen University. The model was run using the simulation program SMART $^{\circledR}$ developed at this university.

\section{Model modifications}

Particle size reduction - In the original model a constant feed intake during the day was assumed and the rumen contents were physically distinguished into particle and fluid fraction. The model included 11 state variables. Undegradable fiber (Fu), degradable fiber (Fd), insoluble starch (Si) and soluble starch and sugars (Sc) represent the carbohydrate fractions in the rumen. Nitrogen-containing fractions include undegradable protein $(\mathrm{Pu})$, insoluble and degradable protein (Pd), soluble protein (Ps) and ammonia (Am). Fatty acid fractions include long chain fatty acids ( $\mathrm{Ld}$ ) and volatile fatty acids (Va) and, the rumen microbial DM (Mi) is represented by one state variable. Detailed description of the model and applications are described in Dijkstra et al. (1996a; 1996b).

To include the effect of particle size reduction in the model, a new state variable for large particles (QLp) was added to the original 11 state variables, and was defined by Eq. [1a]. The concept with a single aggregate large particle (LP) pool comprising all the insoluble components in the diet, except insoluble starch (Si), corresponds to that proposed by Baldwin et al. (1987). A small particle (QSp) zero pool (meaning it is calculated from other pool sizes and flux rate equations) was introduced as the sum of insoluble nutrients in the small particle form, which is directly susceptible to microbial degradation (Eq. [1i]): degradable fiber (QFd), undegradable fiber $(\mathrm{QFu})$, insoluble but degradable protein (QPd) and undegradable protein (QPu) and QSi. The conversion of QLp to QSp was totally dependent upon rumination and was represented as a function of the physical properties of feeds (comminution rate) and the time spent ruminating (Baldwin et al., 1987) (Eq. [1h]).

Quantity of Rumen Large particles (QLp, $g$ ):

$\mathrm{dQLp} / \mathrm{dt}\left(\mathrm{g} \mathrm{h}^{-1}\right)=$ PLpILp-ULpLSp

Lp uptake with feed $\left(g L p h^{-1}\right)$ :

PLPILp $\left(\mathrm{g} \mathrm{h}^{-1}\right)=$ DLp

DLp $\left(\mathrm{g} \mathrm{h}^{-1}\right)=(\mathrm{DFu}+\mathrm{DFd}+\mathrm{DPu}+\mathrm{DPd}) *(1-\mathrm{FSp})$

$\mathrm{DFu}=$ feed $*$ frfu/1000.

DFd $=$ feed $*$ frfd $/ 1000$.

$\mathrm{DPu}=$ feed $*$ frpu/1000.

DPd $=$ feed $*$ frpd $/ 1000$.

feed is the quantity of feed ingested per day $\left(\mathrm{g} \mathrm{d}^{-1}\right)$

$\mathrm{FrFu}, \mathrm{FrFd}$, FrPu, FrPd are the fractions of undegradable NDF, degradable NDF, undegradable protein and degradable protein in the feed $\left(\mathrm{g} \mathrm{kg}^{-1} \mathrm{DM}\right)$.

FSp is the fraction of small particles in feed

Conversion to small particles ( $g$ of $L p h^{-1}$ ):

ULpLSp $=$ kLpSp*Rum*QLp

$\mathrm{kLpSp}$ is the fractional comminution rate $\left(\mathrm{h}^{-1}\right)$, and Rum is the proporption of time spent ruminating during the day (fraction of the day).

A comminution rate or rate of conversion to small particles (kLpSp), of $0.09 \mathrm{~h}^{-1}\left(2.2 \mathrm{~d}^{-1}\right)$ was used because of the low degradability of sugarcane. A value of $4.5 \mathrm{~d}^{-1}$ was proposed by Bannink \& De Visser (1997) because of the high degradability of the fresh perennial ryegrass in the diets evaluated by them. Baldwin (1995) proposed Rum $=0.33$ in continuous feeding. A chewing time of 54 min $\mathrm{kg}^{-1}$ DM was estimated for $7.5 \mathrm{~kg}$ DM intake. Therefore, the Rum parameter was calculated as 0.28 $((7.5 \times 54 / 60) / 24)$. Lignification, DMI, stage of maturity, protein content, and many other features intrinsic to the plant may affect these values.

Quantity of Rumen Small Particles (QSp, g):

$\mathrm{QSp}\left(\mathrm{g} \mathrm{h}^{-1}\right)=\mathrm{QSi}+\mathrm{QFu}+\mathrm{QFd}+\mathrm{QPu}+\mathrm{QPd}$

Description of QFd, QFu, QPd, QPu is similar to original model

Quantity of rumen insoluble starch (Qsi,g) 
$\mathrm{dQSi} / \mathrm{dt}\left(\mathrm{g} \mathrm{h}^{-1}\right)=$ PSiISi - USiSSc - UsiSEx

Quantity of rumen undegradable fiber $(\mathrm{QFu}, \mathrm{g})$

$\mathrm{dQFu} / \mathrm{dt}\left(\mathrm{g} \mathrm{h}^{-1}\right)=$ PFuIFu + PFuLSp - UFuFEx

Uptake of Fu small particle with feed $\left(\mathrm{g} \mathrm{Fu} \mathrm{h}^{-1}\right)$

$\mathrm{PFuIFu}=\mathrm{DFu} * \mathrm{FSp}$

Reduction of particles size of large particle $\mathrm{Fu}\left(\mathrm{g} \mathrm{Fu} \mathrm{h} \mathrm{h}^{-1}\right)$

PFuLSp $=$ ULpLSp *FFLpFu

Fraction of Fu large particles with feed

$\mathrm{FFLpFu}=\mathrm{DFu} *(1-\mathrm{FSp}) / \mathrm{DLp}$

UfuFEx is the Outflow of Fu from rumen $\left(\mathrm{gFu} \mathrm{h}^{-1}\right)$

Quantity of rumen undegradable protein $(\mathrm{QPu}, \mathrm{g})$

$\mathrm{dQPu} / \mathrm{dt}\left(\mathrm{g} \mathrm{h}^{-1}\right)=$ PPuIPu + PPuLSp - UPuPEx

Uptake of Pu small particle with feed $\left(\mathrm{gPu} \mathrm{h}{ }^{-1}\right)$

$\mathrm{PPuIPu}=\mathrm{DPu}{ }^{*} \mathrm{FSp}$

Reduction of particles size of large particle $\mathrm{Pu}\left(\mathrm{g} \mathrm{Pu} \mathrm{h}^{-1}\right)$

PPuLSp $=$ ULpLSp *FFLpPu

Fraction of Pu large particles with feed

$\mathrm{FFLpPu}=\mathrm{DPu} *(1-\mathrm{FSp}) / \mathrm{DLp}$

UPuPEx is the Outflow of Fu from rumen ( $\mathrm{g} \mathrm{Fu} \mathrm{h} \mathrm{h}^{-1}$ )

Quantity of rumen degradable fiber $(\mathrm{QFd}, \mathrm{g}$ )

$\mathrm{dQFd} / \mathrm{dt}\left(\mathrm{g} \mathrm{h}^{-1}\right)=$ PFdIFd + PFdLSp - UFdFSc - UFdFEx

Quantity of rumen degradable protein $(\mathrm{QPd}, \mathrm{g})$

$\mathrm{dQPd} / \mathrm{dt}\left(\mathrm{g} \mathrm{h}^{-1}\right)=$ PPdIPd + PPdLSp - UPdPPs - UPdFEx

Dry matter intake - The steady-state simulation (constant feed intake during the day) in the original model was changed to non steady-state conditions adapting to the work of Miranda et al. (1999). They observed an average number of 12 meals per day in crossbred heifers Holstein X Zebu receiving sugarcane + urea based diets supplemented with $15 \%$ of cotton meal. The experiment showed that $85 \%$ of ingestion occurred during the first 12 hours after single feeding per day, probably, because the offer of fresh diet promotes higher DMI. This ingestive behavior was used to simulate the consumption of $85 \%$ in seven separate meals during the first six hours and $15 \%$ in two other meals the next six hours every 12 hours when the diet is supplied twice in a day.

Because in non-steady state conditions, fluxes continuously vary with time and had to be integrated dur- ing the last 24 hours for calculations of model outcomes. The integration step was reduced to $0.01 \mathrm{~h}$ to ensure that with pulses of feed intake accurate integration results will be obtained. Otherwise, the abrupt changes in pools of small size would easily become exaggerated and lead to unreliable results of the whole model outcome.

Microbial death - A Michaelis-Menten equation had to be introduced to account for the death of microorganisms (UMiMd; Eq. [2a]) in absence of substrate and to reduce the nutrient utilization efficiency of microbial dry matter (Mi). Otherwise, in non steady state conditions such as with the simulation of one or two meals for a few hours during the day, for some negative unrealistic state variable values would be obtained. The death of micro-organisms resulting from this equation was distributed as a new input to the various substrate pools according to the composition of microbial matter used by Dijkstra et al. (1996a).

The average maximum relative microbial death in the absence of substrate (Vmaxd) was defined as 0.4 $\mathrm{h}^{-1}$ considering the average maximum relative growth in vitro of $0.8 \mathrm{~h}^{-1}$ described by Russell \& Baldwin (1978), when preformed monomers were supplied. A very small inhibition constant of Sc to Mi (JScMi) was arbitrarily set at $0.001 \mathrm{~g} \mathrm{l}^{-1}$ based on some preliminary runs and the necessity to avoid negative values of the Sc pool, the value of JScMi.

Quantity of Rumen microbial mass (Q Mi, g):

$\mathrm{dQMi} / \mathrm{dt}\left(\mathrm{g} \mathrm{h}^{-1}\right)=$ PMiAMi + PMiPMi - UMiMEx UmiMd

Rate of death of the microbial mass $\left(\mathrm{g} \mathrm{Mi} \mathrm{h} \mathrm{h}^{-1}\right)$

UMiMd $\left(\mathrm{g} \mathrm{h}^{-1}\right)=\left(\operatorname{Vmaxd}{ }^{*} \mathrm{QMi}\right) /(1+(\mathrm{CSca} / \mathrm{JScMi}))[2 \mathrm{~b}]$

CSca is the concentration of soluble starch and sugar in the rumen ( $\mathrm{g} \mathrm{Sc} \mathrm{l}^{-1}$ )

= QSa / Rumen Volume

Salivary nitrogen - Non-dietary $\mathrm{N}$ inflow is simulated by quantification of the ammonia (Am) production from urea transported across the rumen wall and of saliva production. The amount of dietary $\mathrm{N}$ used in the original equation to determine the non-dietary $\mathrm{N}$ inflow was also adopted in the modified version, with the dietary $\mathrm{N}$ intake being the mean $\mathrm{N}$ intake per day.

Rumen volume - To simulate non-constant feed intake, the volume of rumen fluid $(\mathrm{V})$ changed from a constant parameter in the original model into a variable dependent on the size of the meals and their DM content. A non-linear relationship between DM percentage of the rumen contents (DMC) and the DM rumen pool size (DMRP) was adopted (Eqs. [4a] \& [4b]), according to the equation proposed by Chilibroste et al. (2001). This 
relationship allowed V to vary during the day:

DM percentage of rumen contents:

$\mathrm{DMC}=12.05( \pm 0.19) \times\left(1-\mathrm{e}^{-0.32( \pm 0.17) \times \mathrm{DMRP}}\right)$

DM percentage of rumen content (DMC, \%)

DM rumen pool size (DMRP, kg) calculated as the sum of all non-water pools in the rumen.

$\mathrm{V}=(100 * \mathrm{DMRP} / \mathrm{DMC}-\mathrm{DMRP}) / 1000$

\section{Application of the model}

Sensitivity analysis - To examine the effects of rate of comminution (kLpSp), small particle size fraction (FSp), rumination and mastication times (Rum), inhibition of nutrient utilization (JScMi), velocity of death and utilization of Sc by microbial mass (VMaxD and VScMi), a sensitivity analysis was performed to ensure that the model outputs are appropriated in relation to the parameters included as inputs.

Two reference diets for Holstein X Zebu cows with live weight of $470 \mathrm{~kg}$ were considered for the simulations. Both diets had $60 \%$ of small particles, Rum of 0.28 and intake of $7.5 \mathrm{~kg} \mathrm{DM}$ day $^{-1}$. The first diet had $10 \mathrm{~g}$ of urea $\mathrm{kg}^{-1}$ of fresh sugarcane (Diet C). In the second diet, 20\% of the sugarcane/urea mix was replaced by maize grain (Diet CM). The parameters were set at 0.5, 0.75, 1.0, 1.25 and 1.5 times their values and tested in steady-state and non-steady state conditions. In the latter, a new meal of two hours duration was simulated every 12 hours. Thus, for every diet parameter combination, five steady-state and five non-steady state solutions were obtained. To simulate real conditions kLpSp, Rum and FSP values must be changed together to account for different quantities of DMI or FSp. However, to test the specific sensitivity of each one, the parameters were considered independent and changed one by one in order to test their effect on the simulated quantity of nutrients absorbed and potential milk yields.

Comparison between simulated and experimental values - Two experiments were used to evaluate model performance. Even though a lot of information on sugarcane based diets for ruminants exists, it is difficult to find data sets providing adequate information on nutrient supply and complete nutrient profiles for absorption to allow a full comparison between predicted and observed values.

The first experiment was performed by Matos (1991) using crossbred (B. Taurus x B. indicus) growing steers (290 kg average $\mathrm{LW}$ ) in a factorial design with two levels of DMI (52.5 g DM kg $\mathrm{LW}^{0.75}$ and $78.75 \mathrm{~g} \mathrm{DM}$ $\mathrm{kg}^{-1} \mathrm{LW}^{0.75}$ ) and two levels of urea inclusion (10 or $15 \mathrm{~g}$ $\mathrm{kg}^{-1}$ fresh sugarcane weight) for chopped sugarcane supplemented with rice meal (210 $\mathrm{g} \mathrm{kg}^{-1} \mathrm{DM}$ diet). The actual values for NDF and non-ammonia nitrogen (NAN) rumen outflows and, apparent rumen degradation of starch and sugars (fraction of starch and sugar intake) were compared with model predicted values.

The effect of supplementation of sugarcane based diets with soybean meal and whole soybean on milk production was reported by Assis et al. (1999). They fed 32 dairy cows consuming an average of $11.4 \mathrm{~kg}$ DM with four sugarcane and urea based rations supplemented with $1.6 \mathrm{~kg}$ DM per cow day ${ }^{-1}$ of soybean meal (SM); 1.6 and $3.2 \mathrm{~kg}$ DM per cow day ${ }^{-1}$ of whole soybeans (1.6WS and $3.2 \mathrm{WS}$ respectively) and; $3.1 \mathrm{~kg} \mathrm{DM}$ per cow day ${ }^{-1}$ of a mix with $2.1 \mathrm{~kg}$ DM whole soybeans and $1.0 \mathrm{~kg}$ DM ground corn (WSM). The observed values were used to test the accuracy of the milk production predictions under non-steady state conditions.

Evaluation of prediction results - In both experiments, the mean square prediction error (MSPE) was used to indicate the error of predicted values relative to actual values.

$$
\operatorname{MSPE}=\sum_{i=1}^{n}\left(O_{i}-P_{i}\right)^{2} / n
$$

where, $\mathrm{O}_{\mathrm{i}}$ and $\mathrm{P}_{\mathrm{i}}$ are the observed and predicted values; $\mathrm{i}$ $=1,2, \ldots, \mathrm{n} ; \mathrm{n}$ is the number of experimental observations. The MSPE is decomposed into error due the overall bias of prediction (i), error due to deviation of the regression slope from one (ii), and the error due to disturbance proportion (iii) (Bibby \& Toutenburg, 1977). According to Gerrits (1996), (i) represents the proportion of MSPE, due to a consistent over or underestimation of the experimental observations by model predictions. (ii) Represents the proportion of MSPE, due to inadequate simulation of differences between experimental observations. Finally, (iii) is the fraction unrelated to the errors of model prediction.

\section{RESULTS AND DISCUSSION}

In steady state conditions (constant rate of feed intake) the inclusion of a mechanism of particle size reduction showed exactly the same results as obtained with the original model, even by varying small particle fractions (FSp) and fractional rates of comminution (kLpSp and Rum). This result was expected because under steady-state conditions the sum of inflows to degradable substrate pools in the extended version of the model must remain the same as in the original model. Outflow from the Lp pool equaled the inflow, and outflow from the Lp pool and from the diet contributes to $100 \%$ of the inflow for the Sp pool. In contrast to the result obtained under steady state conditions, for non-steady state conditions with varying patterns of feed intake, the inclusion of a mechanism of particle size reduction did affect the availability of nutrients for microbial use in the rumen and 
consequently resulted in changes in the simulated fluxes and potential milk yield.

Microbial death rate diminished with corn supplementation. The microbial death variable depends on nutrient availability and an extra source of glucose for the Mi diminished the critical time with small Sc pool sizes leading to microbial death. Intake during a few hours per day caused variation in $\mathrm{V}$ and for this reason passage rates were dependent on the pool sizes.

The response of the model was as expected. Supplementation with corn increased the quantity of nutrients absorbed in the intestine. This behavior was already described in the original model. Simulation of non steady-state conditions with intake of two meals during two hours per meal led, at certain moments during the day, to very small values for the rumen pool sizes (some moments with less of one gram of soluble carbohydrates) although simulations of daily digestion, passage and milk production still remained reliable in most cases. The use of the ingestive behavior observations of Miranda et al. (1999) as an input to the model, allowed for a longer availability of nutrients and increased the accuracy of the simulations due to diminished microbial death rates. In simulations of sheep fed alfalfa diets once daily in a three to four hours meal, Murphy et al. (1986) predicted faster ruminal digestion and passage than the ones observed, resulting in smaller pool sizes before feeding. They also reported aberrant model behavior when diets of very low quality were used. Therefore, they concluded that the rates of particle size reduction were not sufficient to maintain fermentation, microbial growth and passage from the rumen in their non-steady state simulations.

Supplementation of sugarcane with corn (Diet $\mathrm{CM}$ ) raised the absorption in the intestine of all the nutrients. Absorbed amino acids were approximately 25\% higher than with the unsupplemented diet. Inclusion of starch delivered more fermentable organic matter and promoted higher yield and outflow of microbial mass to the intestine. Glucose absorption was increased by corn supplementation because a variable proportion of dietary starch escapes rumen fermentation and is subsequently subjected to enzymatic digestion in the small intestine (Nocek \& Tamminga, 1991). The absorption of long chain fatty acids ( $\mathrm{Li}$ ) was almost doubled because of the higher Li content of the corn as compared to the original sugarcane and urea diet and, microbial lipids also contributed to absorbed Li. Inclusion of corn grain did not significantly affect the absorption of volatile fatty acids (AVf), perhaps due to the relatively high total values of AVf in the rumen and other organs for sugarcane diets reported by Leng \& Preston (1976).

Substitution of $20 \%$ of sugarcane with corn also diminished the rumen volume. Because of the rapid fermentation of its organic matter, corn allows faster clearance from the rumen than sugarcane. Sugarcane fiber occupies space in the rumen and requires more time to be chewed and comminuted before escape from the rumen.

The estimates of absorbed nutrients and rumen volume obtained with the two reference diets (C and $\mathrm{CM}$ ) are shown in Table 1.

As commented before, particle size reduction affected the model mainly under non-steady state conditions (NSTST). The differences observed for steady state simulations (STST) were due to changes on V because it is an auxiliary variable which depends on the DM content of the rumen. STST will not be affected if V and flows do not change along the day. The variation in $\mathrm{V}$ affects in principle all fluxes and ruminal concentrations of the nutrients and micro-organisms.

Increase of the particle size reduction by rumination (kLpSp) had moderate effects on AAa and AGl, both with NSTST and STST. Variations reported under STST conditions were due to model adjustment of rumen volume. These results correspond to values obtained by Baldwin et al. (1987). They reported that changing the kLpSp has quite significant effects upon the size of the LP pool but only moderate effects upon predicted digestibility. A higher comminution rate slightly increased the absorption of amino acids. The protein in small particles is likely to be degraded more rapidly than the protein in large particles because of the larger surface area of small particles (Dhiman et al., 1997). In diets with highly rumen degradable protein this can increase the microbial efficiency and, in the presence of adequate carbohydrate fractions, may allow more microbial protein flowing to be digested and absorbed in the small intestine. On the

Table 1 - Reference estimates for absorbed amino acids (AAa), glucose (AGl), long chain fatty acids (ALi) and volatile fatty acids (AVf) from gastrointestinal tract and rumen volume (V) on sugarcane with urea diet (C) or sugarcane with urea and corn grain diet (CM) calculated by the model ${ }^{1}$.

\begin{tabular}{|c|c|c|c|c|c|c|c|c|c|c|}
\hline & \multicolumn{2}{|c|}{$\mathrm{AAa}$} & \multicolumn{2}{|c|}{ AGl } & \multicolumn{2}{|c|}{$\mathrm{ALi}$} & \multicolumn{2}{|c|}{ AVf } & \multicolumn{2}{|c|}{$\mathrm{V}$} \\
\hline & $\mathrm{C}$ & $\mathrm{CM}$ & $\mathrm{C}$ & $\mathrm{CM}$ & $\mathrm{C}$ & $\mathrm{CM}$ & $\mathrm{C}$ & $\mathrm{CM}$ & $\mathrm{C}$ & $\mathrm{CM}$ \\
\hline & - & - & --.-- & $-\cdots$ & -- & -..--.- & $\cdots$ & --n-n- & ------- & $\cdots-\cdots$ \\
\hline $\mathrm{STST}^{1}$ & 337.7 & 420.6 & 257.3 & 416.2 & 60.0 & 96.6 & 39.3 & 44.6 & 62.6 & 60.1 \\
\hline NSTST & 216.0 & 319.5 & 390.0 & 501.9 & 76.0 & 108.5 & 37.0 & 43.0 & 63.6 & 60.1 \\
\hline
\end{tabular}

${ }^{1}$ STST, steady-state conditions; NSTST non steady-state conditions. 
other hand, a faster reduction of sugarcane and corn particles increased the rumen fermentation of non fiber carbohydrates leading to a diminished quantity of starch or sucrose flowing to the intestine and, therefore, a decrease in the absorption of glucose. Higher values of kLpSp decrease the $\mathrm{V}$, an effect which was confirmed by Allen \& Mertens (1988). They stated that fiber digestibility decreases as rate of passage increases, and rate of passage is inversely related to rumen volume at a given level of intake. Several questions concerning kLpSp remain unresolved at present (Baldwin, 1995): whether kLpSp should be a function of the physical properties of feeds, or a function of fermentation rate, and whether the time needed for the ingested feeds to become hydrated puts a delay on the availability of feeds for microbial degradation.

Sensitivity analysis - The sensitivity of the six parameters after changing the reference values at 0.5 , $0.75,1.0,1.25$ and 1.5 times are given in Table 2.

Some of the parameters tested in the sensitivity analysis are dependent on other. This means that with actual simulation studies these parameters need to be changed together to ensure a reliable performance of the model. The fraction of small particles (FSp), for example, should affect the time spent ruminating (Rum).

Eq. [1h] assumes that Rum and kLpSp have direct relation to determine the output of Lp pool and should have same sensitivity as observed for STST. How- ever, in NSTST, the sensitivities of both parameters were different. The differences in quantities of absorbed nutrients were due to differences in microbial population. Eq. [2a] and [2b] control excessive microbial utilization of nutrients and a small soluble nutrient pool leads to increased microbial death.

Sensitivity analyses revealed that the absorption of nutrients was highly sensitive to changes in the rate of utilisation of soluble starch and sugars (Sc) for microbial maintenance (vScMi). A fast liberation of soluble carbohydrates from diets with fastening periods of 10 hours leads to substantial periods of time without new substrates which affects apparent bacterial yield by increased rate of death due to a lack of carbon skeletons and availability of energy (ATP) for microbial synthesis.

\section{Comparison between observed and predicted values}

The model was tested with independent observations for growing cattle (Matos, 1991) and dairy cows (Assis et al., 1999).

Nutrient outflows and apparent rumen digestion - For growing cattle, a comparison was made between predicted and observed values of duodenal flow of NDF and NAN and apparent rumen digestion of starch and sugars.

Individual simulations of NDF outflows were quite close to actual values (Figure 1) with a root MSPE of $14.2 \%$ of the observed mean. Random disturbance pro-

Table 2 - Average slopes of regression lines for absorbed nutrients from gastrointestinal tract and rumen volume (V) on sugarcane with urea diet (C) or sugarcane with urea and corn grain diet (CM), obtained by perturbing selected parameter in turn ${ }^{1}$.

\begin{tabular}{|c|c|c|c|c|c|c|c|c|c|c|}
\hline \multirow{2}{*}{$\begin{array}{l}\text { Perturbed } \\
\text { parameter }\end{array}$} & \multicolumn{2}{|c|}{ Aaа } & \multicolumn{2}{|c|}{ AGl } & \multicolumn{2}{|c|}{ ALi } & \multicolumn{2}{|c|}{$\mathrm{AVf}$} & \multicolumn{2}{|c|}{$\mathrm{V}$} \\
\hline & $\mathrm{C}$ & $\mathrm{CM}$ & $\mathrm{C}$ & $\mathrm{CM}$ & $\mathrm{C}$ & $\mathrm{CM}$ & $\mathrm{C}$ & $\mathrm{CM}$ & $\mathrm{C}$ & $\mathrm{CM}$ \\
\hline & \multicolumn{6}{|c|}{ - } & \multicolumn{2}{|c|}{$---\operatorname{mol~d}^{-1}---$} & \multicolumn{2}{|c|}{$----1-1-\cdots$} \\
\hline kLpSp STST ${ }^{1}$ & 16.9 & 12.9 & -21.7 & -29.8 & 0.4 & 0.5 & 2.3 & 2.4 & -21.1 & -18.6 \\
\hline kLpSp NSTST & 1.9 & 19.0 & -80.8 & -62.1 & -0.3 & -1.0 & 3.3 & 3.5 & -21.2 & -19.0 \\
\hline Rum STST & 17.7 & 13.6 & -22.8 & -31.3 & 0.4 & 0.5 & 2.4 & 2.6 & -22.1 & -19.6 \\
\hline Rum NSTST & -40.3 & -37.5 & 55.6 & 11.1 & 7.8 & 6.2 & 0.5 & 1.8 & -21.4 & -19.1 \\
\hline FSp STST & 21.7 & 10.5 & -25.5 & -35.8 & 0.5 & 0.4 & 2.9 & 3.2 & -25.5 & -22.3 \\
\hline FSp NSTST & -15.6 & -10.5 & 21.5 & -12.5 & 3.8 & 3.5 & 1.9 & 2.0 & -24.9 & -22.4 \\
\hline Vmaxd STST & -1.8 & -2.3 & -0.7 & -0.7 & 0.4 & 0.6 & 0.0 & 0.0 & 0.0 & 0.0 \\
\hline Vmaxd NSTST & -2.1 & -5.4 & 3.3 & 3.4 & 0.4 & 0.8 & -0.1 & -0.1 & 0.0 & 0.1 \\
\hline JScMi STST & -1.8 & -2.3 & -0.8 & -0.7 & 0.4 & 0.6 & 0.0 & 0.0 & 0.0 & 0.0 \\
\hline JScMi NSTST & -1.8 & -4.9 & 2.6 & 3.4 & 0.3 & 0.7 & -0.1 & -0.1 & 0.0 & 0.1 \\
\hline vScMi STST & -126.8 & -277.0 & -116.9 & -88.8 & -2.8 & -8.0 & 0.6 & 2.6 & -0.8 & -1.0 \\
\hline vScMi NSTST & -192.0 & -239.4 & 183.8 & 94.8 & 12.4 & 11.7 & -5.7 & -4.8 & 1.7 & 2.1 \\
\hline
\end{tabular}

${ }^{1}$ STST, steady-state conditions; NSTST, non steady-state conditions; kLpSp, Fractional comminution rate; FSp, Fraction of small particles in feed; Rum, ruminating factor; Vmaxd, average maximum death rate of microorganisms; JScMi, Inhibition constant of utilization of soluble starch and sugars by the microbial mass; VScMi, Maximum rate of utilization of soluble starch and sugars for microbial mass maintenance 
portion represented $91.2 \%$ of MSPE, $7.5 \%$ to the overall bias and $1.3 \%$ to the deviation of the regression slope from one. The model did not under- or over-estimate the experimental observations. The very small contribution of the deviation of the regression slope indicates that the variation of observed NDF flows could be closely reproduced by the model. Therefore, the mechanisms of fibrolytic activity in the rumen seem to be well represented by the model. Supplementation with urea slightly increased simulated rumen fibre degradation (Table 3).

Also the predicted NAN flows are in general agreement with observed values (Figure 2). Both actual and predicted values of NAN flow to the duodenum were lower than the rate of $\mathrm{N}$ ingestion with feed. The root MSPE represented 8.5 g, i.e., 15.3\% of the observed mean. The contribution of the random variation to MSPE was $91.7 \%$. The model simulated precisely the effect of increasing intake on rumen NAN outflow. Matos (1991) found effects $(P<0.05)$ on NAN outflow due to the level of ingestion with $45.8 \mathrm{~g} \mathrm{~d}^{-1}$ and $63.1 \mathrm{~g} \mathrm{~d}^{-1}$ for low and

Table 3 - Predicted and observed means of NDF and NAN rumen outflow $\left(\mathrm{g} \mathrm{d}^{-1}\right)$ and apparent rumen degradation of starch and sugars (StSu, \%) of different levels of intake and urea inclusion ${ }^{1}$.

\begin{tabular}{lcccc}
\hline & LI & HI & LU & HU \\
\hline NDF outflow & & & & \\
Matos (1991) & 1163.3 & 1689.6 & 1440.9 & 1433.4 \\
Predicted & 1239.8 & 1726.2 & 1526.7 & 1461.4 \\
\hline NAN outflow & & & & \\
Matos (1991) & 47.5 & 62.4 & 55.8 & 54.7 \\
Predicted & 43.2 & 63.5 & 52.3 & 52.4 \\
\hline StSu degradation & & & & \\
Matos (1991) & 91.1 & 90.7 & 90.5 & 91.2 \\
Predicted & 89.1 & 89.9 & 89.2 & 89.7 \\
\hline
\end{tabular}

${ }^{1} \mathrm{LI}$, low intake; HI, high intake; LU, $10 \mathrm{~g}$ urea $\mathrm{kg}^{-1}$ fresh sugarcane; $\mathrm{HU}, 15 \mathrm{~g}$ urea $\mathrm{kg}^{-1}$ fresh sugarcane.

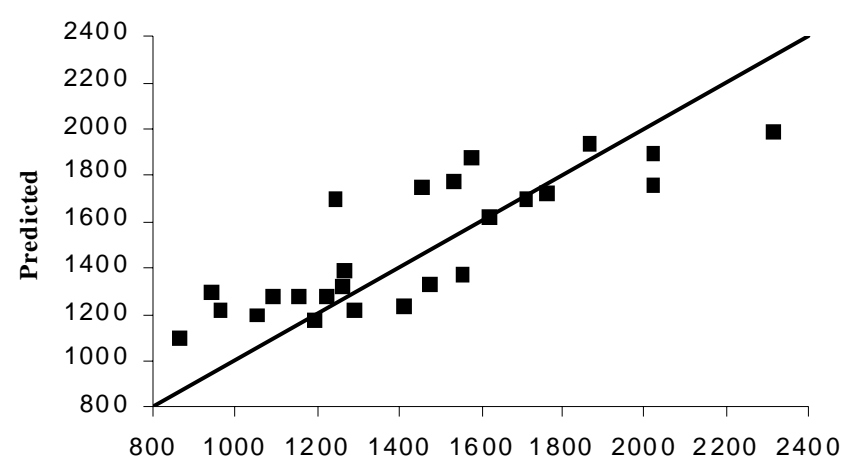

observed

Figure 1 - Observed and predicted rate of NDF outflow from the rumen $\left(\mathrm{g} \mathrm{d}^{-1}\right)$. high intakes. Average means of predicted values for both levels were 43.2 and $63.7 \mathrm{~g} \mathrm{~d}^{-1}$. An increased level of dietary urea from 1 to $1.5 \%$ in a sugarcane based diet supplemented with rice meal did not affect predicted outflow rate of NAN (52.3 and $51.7 \mathrm{~g} \mathrm{~d}^{-1}$ ), which corresponds to the observations by Matos (1991) who also could not establish an effect (56.8 and $53.0 \mathrm{~g} \mathrm{~d}^{-1}$ ). Mendonça et al. (2002) affirmed that apparent digestibility of dry matter, organic matter, crude protein and total carbohydrates were not influenced by the different levels of urea in sugarcane diets.

The overall mean of the Sc degradation was less well predicted than for NDF and NAN and the simulation results show a consistent underprediction (Figure 3). Simulated apparent rumen digestion of starch and sugars tended to be lower than the observed (root MSPE of 2.7\% of real mean) with an overall bias and deviation from the regression slope from unity contributing $30.2 \%$ and $8.7 \%$ to the MSPE. Further evaluation of the prediction accuracy of the model in non steady-state conditions requires more experiments in which the effects of ingestive behaviour on rumen function would be tested. According to Neal et al. (1992), differences between simulated and observed values should not be considered entirely due to inadequacy of the model, because inadequacies of input data describing the diets or errors in experimental measurements could also contribute to these differences.

Milk production - Assis et al. (1999) set up a feeding trial with dairy cows in order to validate the original model. Their data were used to test the behavior of the new version of the rumen model. They obtained accurate predictions with low lipid diets. However, with 3.2 $\mathrm{kg} \mathrm{DM}$ of whole soybean in the ration, the original model predicted less well. Therefore, Assis et al. (1999) decided to exclude the treatment with the high inclusion $(3.2 \mathrm{~kg})$ of whole soybean from the validation test and concluded that for diets with higher lipid levels, i.e. whole soybean, rice meal, cottonseeds, etc., the original model behavior was unsatisfactory.

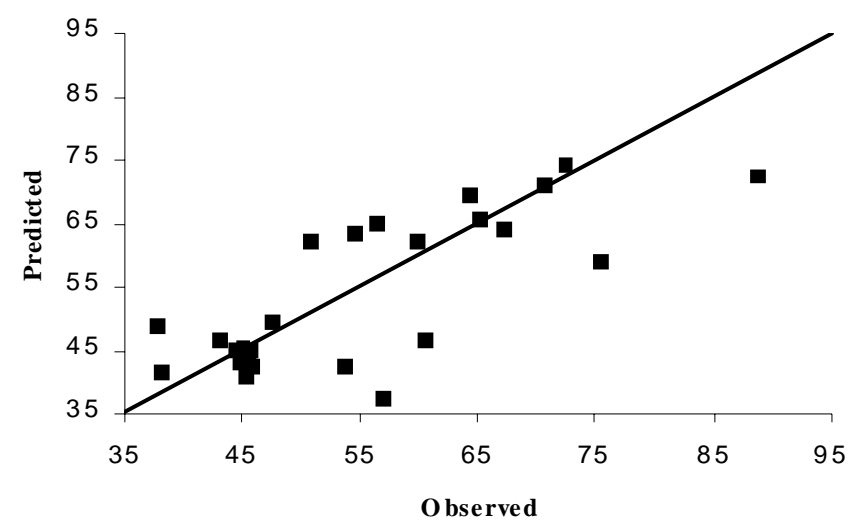

Figure 2 - Observed and predicted rate of NAN outflow from the rumen $\left(\mathrm{g} \mathrm{d}^{-1}\right)$. 
In contrast to this previous validation test, a similar test with the new version of the rumen model used in the present study indicated good predictive behavior for all four treatments. The model simulates the absorbed amounts of amino acids, glucose, long chain fatty acids and volatile fatty acids. In lactating cows, the milk production milk is defined by the most limiting nutrient, even if the other nutrients present potentials for higher production. As shown in Figure 4, predictions of milk production (11.0 L d $\left.\mathrm{d}^{-1}\right)$ using energy, protein and glucose as predictors were quite close to real observations $\left(11.2 \mathrm{~L} \mathrm{~d}^{-1}\right)$. Simulations presented a root MSPE of $3.4 \mathrm{~L} \mathrm{~d}^{-1}$, i.e., $16.5 \%$ of the observed mean and $76.5 \%$ of MSPE attributed to the random disturbance proportion. The model did not present consistent bias in relation to the behavior of the observed data. Less than 1\% of MSPE was attributed to overall bias deviation and $22.7 \%$ of MSPE to deviation of the regression slope from one. While the overall mean was predicted accurately, the observed variation in milk production caused by different supplements had some bias, possibly due to the small effect reported with different treatments.

The simulated production is based on the most limiting nutrient. The previous simulations indicated that protein requirements for milk production were not fulfilled by the offered rations in three (SM, 1.6 WS and 3.2WS) of the four treatments. Therefore, it would be nec-

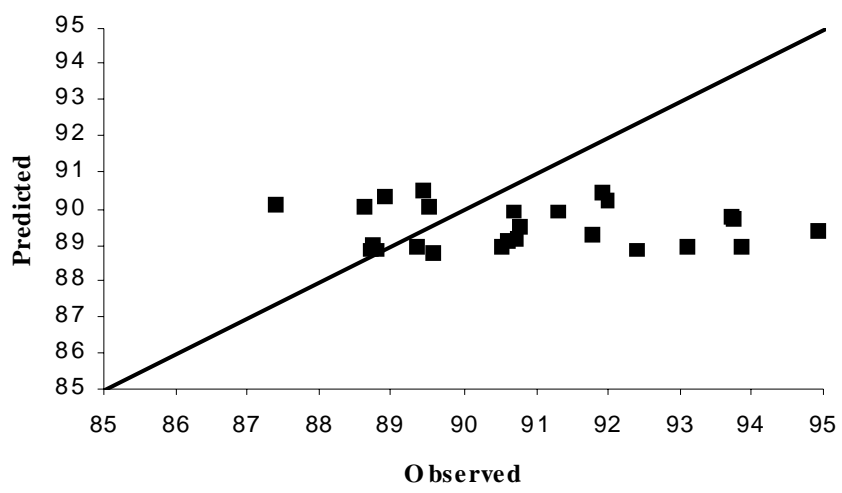

Figure 3 - Observed and predicted apparent rumen digestion of starch and sugars (\%).

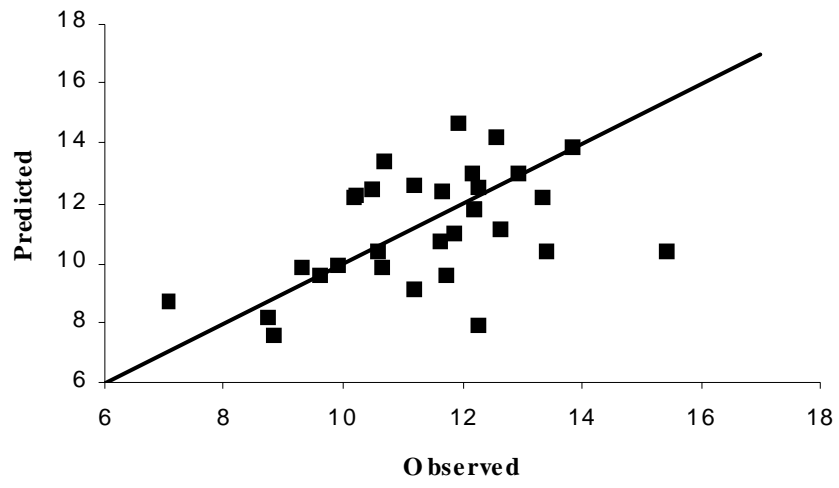

Figure 4 - Observed and predicted values of daily milk production (l). essary to include true protein sources in sugarcane based diets supplemented with whole soybeans and corn to adjust the protein to the level of the other nutrients. Differently from the results of Assis et al. (1999), the new version indicated energy as the most limiting nutrient in the treatment with sugarcane supplemented with $1.6 \mathrm{~kg}$ DM of soybean meal.

The results obtained in the present study seem more realistic because the protein fraction in soybeans as a supplement for cattle is highly degradable in the rumen which may result in low quantity of this protein fraction reaching the small intestine. Ganesh \& Grieve (2002) reported that soybean meal has approximately $30 \%$ more nitrogen than raw soybeans on a dry matter basis, $8.89 \%$ and $6.85 \%$ per kg DM respectively. The soluble fraction of nitrogen of soybean meal is less than $50 \%$ of that of raw soybeans (22.71 and 47.78 percent of total nitrogen, respectively). NPN in soluble nitrogen is also higher in raw soybeans. Therefore, the addition of higher quantities of soluble nitrogen in diets supplemented with urea will not increase the amino acids in the intestine; neither will a source of rumen undegradable protein as soybean meal. Dawson et al. (1988) reported that supplementary protein feeds of inherently low rumen degradability like soybean meal have direct effects on the amount of undegraded dietary protein passing to the duodenum, but can also increase protein flow by stimulating carbohydrate digestion and microbial protein synthesis. In general, if can be said that the new model demonstrated good capability to predict milk production from cows fed sugarcane based diets supplemented with low or high lipid content.

\section{CONCLUSIONS}

A mechanistic model can be used for the prediction of nutrient absorption and production of cattle with reliable results. The model responds well to changes in the quantity and quality of feed offered under non steadystate conditions and seems to be useful to select strategies for supplementation of sugarcane based diets. Predicted outflow from the rumen generally corresponded with observed values. However, prediction of apparent rumen digestion of starch and sugar needs to be improved with more experimental data.

\section{ACKNOWLEDGMENTS}

To the members of the Animal Nutrition Group of Wageningen Agricultural University, especially Professor Seerp Tamminga, and for financial support by CNPq.

\section{REFERENCES}

ALLEN, M.S. Effects of diet on short-term regulation of feed intake by lactating dairy cattle. Journal of Dairy Science, v.83, p.1598-1624, 2000. 
ALLEN, M.S.; MERTENS, D.R. Evaluating constraints on fiber digestion by rumen microbes. Journal of Nutrition, v.118, p.261-270, 1988.

ASSIS, A.G.; LOPES, F.C.F.; DURÃES, M.C.; SIMÕES, J.B.; ANDRADE, R.S.; VERARDO JR., A.E. Validação de um modelo de simulação da cinética de nutrientes em vacas leiteiras. In: REUNIÃO ANUAL DA SOCIEDADE BRASILEIRA DE ZOOTECNIA, 36., Porto Alegre, 1999. Anais. São Paulo: Gnosis, 1999.. Nutrição de ruminantes. NUR-008. 1 CD-ROM

BALDWIN, R.L. Modeling ruminant digestion and metabolism. London: Chapman \& Hall, 1995. 592p.

BALDWIN, R.L.; THORNLEY, J.H.M.; BEEVER, D.E. Metabolism of the lactating cow. II. Digestive elements of a mechanistic model. Journal of Dairy Research, v.54, p.107-131, 1987.

BANNINK, A.; DE VISSER, H. Comparison of mechanistic rumen models on mathematical formulation of extramicrobial and microbial processes. Journal of Dairy Science, v.80, p.1296-1314, 1997.

BIBBY, J.; TOUTENBURG, H. Prediction and improved estimation in linear models. Chichester: John Wiley \& Sons, 1977. 188p.

CHILIBROSTE, P.; DIJKSTRA, J.; TAMMINGA, S. Design and evaluation of a non-steady state rumen model. Netherlands Journal of Agricultural Science, v.49, p.297-312, 2001.

CORREA, C.E.S.; PEREIRA, M.N.; OLIVEIRA, S.G. de; RAMOS, M.H. Performance of Holstein cows fed sugarcane or corn silages of different grain textures. Scientia Agricola, v.60, p.621-629, 2003.

DAWSON, J.M.; BRUCE, C.I.; BUTTERY, P.J.; GILL, M.; BEEVER, D.E. Protein metabolism in the rumen of silage-fed steers: effect of fishmeal supplementation. British Journal of Nutrition, v.60, p.339-353, 1988.

DHIMAN, T.R.; KOREVAAR, A.C.; SATTER, L.D. Particle size of roasted soybeans and the effect on milk production of dairy cows. Journal of Dairy Science, v.80, p.1722-1727, 1997.

DIJKSTRA, J.; FRANCE, J.; NEAL, H.D.ST.C.; ASSIS, A.G.; AROEIRA, L.J.M.; CAMPOS, O.F. Simulation of digestion in cattle fed sugar cane: model development. Journal of Agricultural Science, v.127, p.231246, 1996a.

DIJKSTRA, J.; FRANCE, J.; ASSIS, A.G.; NEAL, H.D.ST.C.; CAMPOS, O.F.; AROEIRA, L.J.M. Simulation of digestion in cattle fed sugar cane: prediction of nutrient supply for milk production with locally available supplements. Journal of Agricultural Science, v.127, p.247-260, 1996 b.

GANESH, D.; GRIEVE, D.G. Effect of roasting raw soybeans at three temperatures on in situ dry matter and nitrogen disappearance in dairy cows. Journal of Dairy Science, v.73, p.3222-3230, 2002.

GERRITS, W.J.J. Modelling the growth of preruminant calves. Wageningen: Wageningen Agricultural University, 1996. 195p. (Thesis-Ph.D.)
KUSMARTONO, A.; SHIMADA, A.; STAFFORD, K.J. Intra-ruminal particle size reduction in deer fed fresh perennial ryegrass (Lolium perenne) or chicory (Cichorium intybus). Journal of Agricultural Science, v.127, p.525-531, 1996.

LAREDO, M.A.; MINSON, D.J. The voluntary intake, digestibility, and retention time by sheep of leaf and stem fractions of five grasses. Australian Journal of Agricultural Research, v.24, p.875-888, 1973.

LENG, R.A.; PRESTON, T.R. Sugarcane for cattle production: Present constraints, perspectives and research priorities. Tropical Animal Production, v.1, p.1-22, 1976.

MATOS, J.M. Níveis de ingestão de alimentos e de uréia sobre alguns parâmetros ruminais e digestão total e parcial em bovinos, alimentados com dieta à base de cana-de-açúcar e uréia suplementada com farelo de arroz. Viçosa: UFV, 1991. 119p. (Tese - Doutorado).

MENDONÇA, S.S.; CAMPOS, J.M.S.; VALADARES FILHO, S.C.; VALADARES, R.F.D.; LANA, R. de P.; SOARES, C.A.; PINA D.dos S.; MACHADO, J.C. Cana-de-açúcar como volumoso único para vacas de leite. 3. Consumo e digestibilidade aparente dos nutrientes In: REUNIÃO ANUAL DA SOCIEDADE BRASILEIRA DE ZOOTECNIA, 39., Recife, 2002. Anais. Recife: SBZ, 2002. 1 CD ROM.

MIRANDA, L.F.; QUEIROZ, A.C. de; VALADARES FILHO, S.C.; CECON, P.R.; PEREIRA, E.S.; SOUZA, J.M.C. de; LANNA, R.P.; MIRANDA, J.F. Comportamento ingestivo de novilhas leiteiras alimentadas com dietas à base de cana-de-açúcar. Revista Brasileira de Zootecnia, v.28, p.614-620, 1999.

MURPHY, M.R.; BALDWIN, R.L.; ULYATT, M.J. An update of a dynamic model of ruminant digestion. Journal of Animal Science, v.62, p.14121422, 1986

NEAL, H.D.ST.C.; DIJKSTRA, J.; GILL, M. Simulation of nutrient digestion, absorption and outflow in the rumen: model evaluation. Journal of Nutrition, v.122, p.2257-2272, 1992.

NOCEK, J.E.; TAMMINGA, S. Site of digestion of starch in the gastrointestinal tract of dairy cows and its effect on milk yield and composition. Journal of Dairy Science, v.74, p.3598-3629, 1991.

RUSSELL, J.B.; BALDWIN, R.L. Substrate preferences in rumen bacteria: evidence of catabolite regulatory mechanisms. Applied and Environmental Microbiology, v.36, p.319-329, 1978.

Received May 06, 2004

Accepted January 24, 2005 